\title{
SARM1 Gene
}

National Cancer Institute

\section{Source}

National Cancer Institute. SARM1 Gene. NCI Thesaurus. Code C102779.

This gene is involved in both signaling and immunity. 